
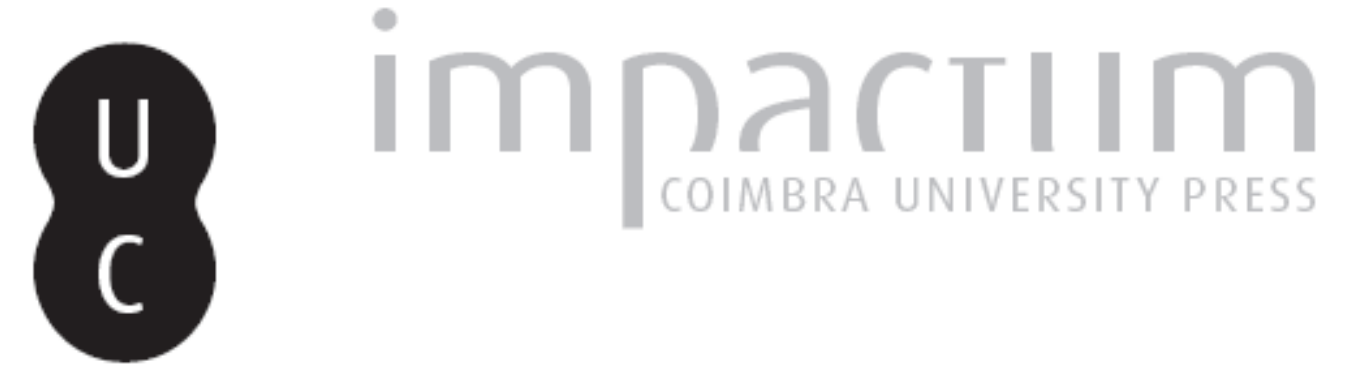

Sobre a experiência da vida consciente: leituras Biranianas

Autor(es): Umbelino, Luís António

Publicado por: Faculdade de Letras da Universidade de Coimbra, Instituto de Estudos

URL

persistente: Filosóficos

DOI: DOI:http://dx.doi.org/10.14195/0872-0851_33_3

Accessed : $\quad$ 26-Apr-2023 13:04:14

A navegação consulta e descarregamento dos títulos inseridos nas Bibliotecas Digitais UC Digitalis, UC Pombalina e UC Impactum, pressupõem a aceitação plena e sem reservas dos Termos e Condições de Uso destas Bibliotecas Digitais, disponíveis em https://digitalis.uc.pt/pt-pt/termos.

Conforme exposto nos referidos Termos e Condições de Uso, o descarregamento de títulos de acesso restrito requer uma licença válida de autorização devendo o utilizador aceder ao(s) documento(s) a partir de um endereço de IP da instituição detentora da supramencionada licença.

Ao utilizador é apenas permitido o descarregamento para uso pessoal, pelo que o emprego do(s) título(s) descarregado(s) para outro fim, designadamente comercial, carece de autorização do respetivo autor ou editor da obra.

Na medida em que todas as obras da UC Digitalis se encontram protegidas pelo Código do Direito de Autor e Direitos Conexos e demais legislação aplicável, toda a cópia, parcial ou total, deste documento, nos casos em que é legalmente admitida, deverá conter ou fazer-se acompanhar por este aviso.

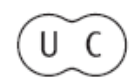




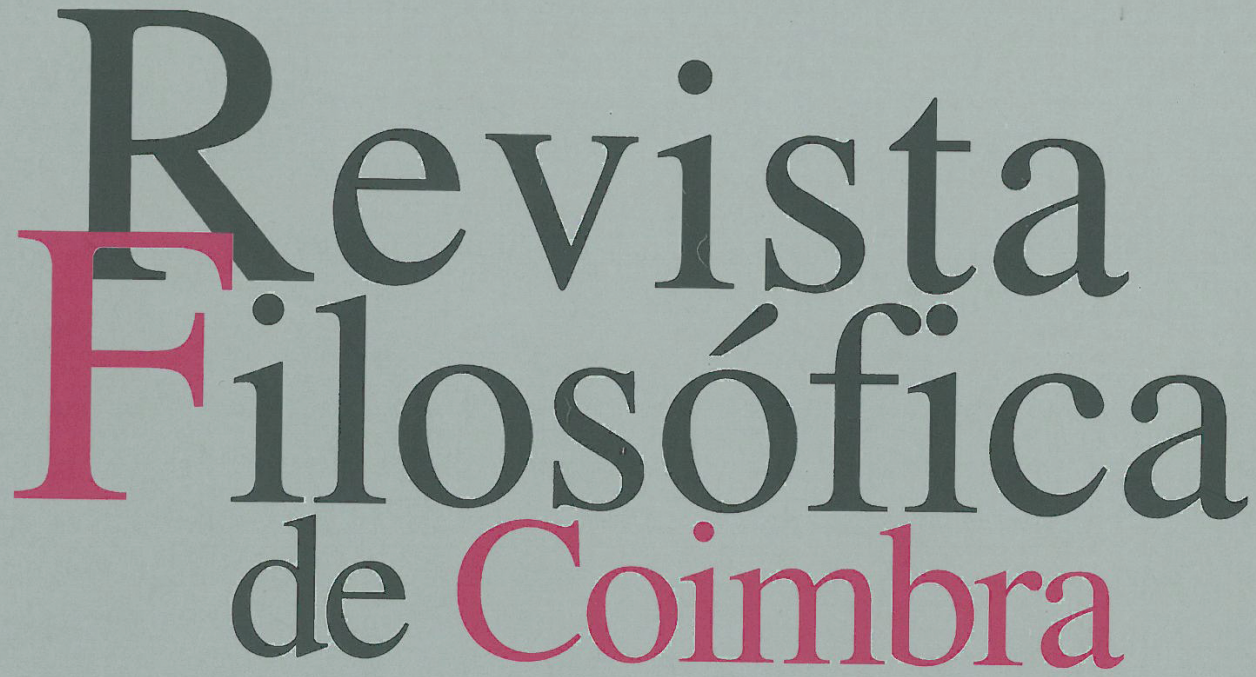

vol.17| n. .33 | 2008

Mário Santiago de Carvalho Fernanda Bernardo Luís António Umbelino Jean-Christophe Goddard Rui Alexandre Grácio Artur Ramos Luís M. Augusto Maria Luísa Portocarrero Jérôme Porée Diogo Ferrer Cláudio Alexandre Carvalho 


\title{
SOBRE A EXPERIÊNCIA DA VIDA CONSCIENTE. LEITURAS BIRANIANAS
}

\author{
LUÍS ANTÓNIO UMBELINO \\ (Universidade de Coimbra)
}

Resumo: O presente trabalho procura meditar as implicações filosóficas mais relevantes da descoberta biraniana da ligação entre consciência e corpo. Organiza-se ao longo dos seguintes momentos: consideração do que significa ser consciente de si numa dualidade que o esforço revela profundamente corporal; ponderação do sentido que, em Maine de Biran, assume a afirmação de um pensamento que funda raízes num plano de resistência e consistência sem o qual desaparece; aprofundamento de uma reflexão sobre o corpo do pensamento; encontro insólito, nas fronteiras porosas da consciência, com um corpo fluído e rebelde capaz de interceptar a posse de si.

\section{1.}

Uma ideia "magistral"1 resume o núcleo mais original da filosofia biraniana: a consciência de si, a apercepção deriva de uma relação de esforço entre uma força da vontade e um corpo resistente. Biran di-lo explicitamente: nas raízes dessa força própria (e sui generis) de vontade e de acção ${ }^{2}$, actualmente aplicada a mover o corpo $^{3}$, sabemos que a

${ }_{1}^{1}$ MONTEBELlO, P., Nature et subjectivité, Million, Grenoble, 2007, p. 23.

${ }^{2}$ MAINE de BIRAN, Mémoire sur la décomposition de la pensée, in CEuvres de Maine de Biran, t. III, ed. Vrin, Paris, p. 102 (Décomposition). À excepção do Journal (3 vol.), editado por Henri Gouhier nas Éditions de la Baconnière, todos os textos de Biran serão citados na mesma edição Vrin. Assim referiremos: Dernière philosophie. Existence et anthropologie (Dernière philosophie); Discours à la Société Médicale de Bergerac (Discours); Essai sur les fondements de la psychologie (Essai); Rapports du physique et du moral de l'homme (Rapports); Nouvelles considérations sur les rapports du physique et du moral de l'homme (Nouvelles considérations); De l'aperception immédiate. Mémoire de Berlin (De l'aperception); Commentaires et marginalia: Dix-neuvième siècle (Commentaires XIX); Correspondance philosophique 1766-1804.

${ }^{3}$ Essai, I, p. 9. 
certeza de si $\left(\mathrm{o}\right.$ eu $\left.{ }^{4}\right)$ "se identificará completamente com o sentimento primitivo da nossa existência individual, na concepção reflexiva de uma força que apenas se torna viva ou consciente dela própria pelo seu desenrolar actual sobre o seu termo de aplicação apropriado"5, que é "resistente ou inerte" 6 .

Grande impensado da tradição filosófica, a relação interior e irrepresentável da vontade ao corpo resistente, distinto mas não separado, resume, no contexto do biranismo, a condição primitiva de um saber(-se) como actividade corporalmente enraizada. De facto, no esforço, a força da vontade percebe imediatamente o efeito de si sobre a resistência muscular, o que significa que se apercebe a ela própria na produção de um efeito que não a perde mas lhe permite concentrar-se sobre si. No esforço, pois, a força da vontade conhece-se no seu princípio como no seu efeito, sem precisar de sair da esfera interior de certeza estabelecida pela sua própria aplicação ao termo que lhe resiste. Quer isto dizer que, na relação que o esforço é, o efeito não será nunca verdadeiramente sentido no exterior da causa $^{7}$ : exercendo-se a força da vontade (a causa-eu), o efeito é imediatamente conhecido na resistência que lhe co-responde; resistindo o corpo de modo interiormente ajustado à vontade, está dada e conhecida a causa, sendo esta o próprio sujeito do esforço.

Esse corpo, explicitemo-lo, nunca é dado à consciência como objecto, antes sendo dado com ela enquanto pólo real, resistente e consistente, disposto e disponível à força da vontade. Por outro lado, a força da vontade não representa qualquer modo particular de um pensamento inclusivo, mas o pólo hiperorgânio da mesma relação que se concretiza num corpo interiormente resistente. Vontade e corpo resistente não

${ }^{4}$ Décomposition, versão premiada, p. 102. Cf., num mesmo sentido, Essai, I, p. 123: «Le sens interne de l'effort ne peut au contraire être mis en jeu que par cette force intérieure et sui generis que nous appelons volonté».

${ }^{5}$ Décompoition, versão premiada, p. 125.

${ }^{6}$ Essai, I, p. 9.

${ }^{7}$ Cf. Décomposition, versão premiada, p. 47. «(...) l'effet n'est point donné ou senti indépendamment de sa cause, puisque la puissance s'aperçoit elle-même dans la production de son effet.» Eis uma diferença que representa um limite incontornável da extensão de aplicação da inspiração experimental a um domínio que pretende esclarecer os "mistérios" do pensar. $\mathrm{O}$ valor individual de causa não pode ser abstraído no âmbito de uma ciência do homem. O fisiólogo procura representar a causa que produz as faculdades, ou seja, parte do pressuposto de que essa causa pode ser reduzida a uma imagem objectiva; esquece, no entanto, que de um ponto de vista reflexivo essa causa é já sempre conhecida como inseparável do próprio sujeito que se constitui através dela. Qualquer tentativa de redução à exterioridade não pode ser vista senão como desvirtuamento da sua realidade. 
correspondem, no esforço, no entanto, a duas ordens distintas de factos, mas apenas a uma; são elementos constitutivos - e, por isso, indissociáveis - de uma relação fora da qual não existem enquanto tal; formam, por assim dizer, um facto relativo ${ }^{8}$ que, para o filósofo de Bergerac, resume a "base ou a primeira condição" à qual se pode ligar o "facto primitivo da individualidade" 9 . Para Biran, pois, a efectuação consciente não depende nem de um inventário de condições orgânicas, nem de uma volição particular, mas do próprio acto que somos; ela tece-se de uma estrutura dual que tem o corpo como elemento constitutivo. Não pensamos sem corpo, não temos consciência sem corpo.

Pelo que fica dito, deve entender-se que o sujeito do esforço não se conhece como princípio lógico, termo abstracto, substancial ou absoluto, mas antes como ex-istência tensional que se apercebe de si no "sentimento íntimo" de ser "causa ou força produtiva" 10 na co-respondência de um corpo próprio. Não é dizer pouco: onde a tradição dos vários absolutos metafísicos julgou encontrar a substância, a essência, o absoluto, o dado definitivo, a permanência, desvenda Maine de Biran a dualidade ${ }^{11}$ em acto, o diverso, o activo, o tensional, o exercício perseverante de uma acção. Àqueles absolutos nunca Biran deixará, então, de opor uma via da relação, que o facto primitivo inaugura - esse mesmo facto primitivo que, estabelecido no esforço, é a fonte "ontogenética", individual e real ${ }^{12}$ (na actualização recíproca dos dois termos que compõem o esforço), de um "si mesmo" uno na dualidade, "modelo"13 e "horizonte transcendental" de todo o conhecimento, o, bem como a origem dos ritmos de uma existência psicológica complexa.

${ }^{8}$ Commentaires XIX, p. 321.

${ }^{9}$ Essai, I, p. 137.

${ }^{10}$ De l'aperception, p. 28.

${ }^{11}$ Cf. ID, o. c., pp. 26, 28. «Le sujet de l'action qui est moi, ne peut être complètement isolé de son terme et le point de vue qui le présente ainsi n'est qu'une pure abstraction réalisée».

12 ID, o.c., p. 27.

${ }^{13}$ Cf. Essai, I, p. 116; Cf. Décompostition, versão premiada, p. 71-72; veja-se igualmente p. 102. «Pour approcher du moins davantage de ce point obscur, et donner s'il est possible à l'analyse un commencement dont elle ne me paraît pas pouvoir se passer, je sens le besoin de creuser plus profondément jusqu'aux racines de cette puissance propre (et sui generis) de volonté et d'action constitutive de la personne même». A tese de fundo é apresentada cedo neste mesmo texto: «Dans la science réfléchie de nos facultés (je ne parle ici que des facultés actives qui elles seules se réfléchissent dans leur exercice comme nous verrons) au contraire, l'effet n'est point donné ou senti indépendamment de sa cause, puisque la puissance s'aperçoit elle-même dans la production de son effet. Ainsi l'acte ou le mouvement qui suit ou accompagne l'effort crée par le moi, n'est perçu comme produit volontaire que dans le sentiment de sa cause ou l'idée réfléchie du vouloir ». Num sentido semelhante, cf. De l'aperception, p. 119. 
Compreende-se que seja a ausência da consideração real e não apenas abstracta, lógica ou físico-fisiológica do princípio numa ciência dos princípios das nossas faculdades e das nossas ideias o que Biran mais deplorará nos trabalhos dos seus contemporâneos, como nas diversas tradições de pensamento de que são, directa ou indirectamente, herdeiros. Apontará tal lacuna em todos os sistemas que procuram estabelecer esse princípio "lá onde o $e u$ fenomenal não existe e não pode existir ainda"14, em todas "as doutrinas filosóficas que tomam num sentido abstracto ou geral os termos próprios das operações da inteligência", em toda e qualquer "teoria puramente fisiológica das funções ou resultados das funções, analisadas ou materialmente decompostas nos seus instrumentos ou centros orgânicos", em qualquer "método lógico de classificação dos modos transformados de uma sensibilidade passiva (...) abstracção feita da causa ou força real", em qualquer perspectiva que se pretenda fundar em "noções sobrenaturais misteriosas dessa causa subjectiva, realizada na ordem dos absolutos, fora de todos os produtos efectuados na existência real, e como que reduzida a certas formas inatas." 15 Por igual enferma estes sistemas a incapacidade em reconhecer a irredutibilidade de uma ordem primitiva de ser singular, ordem propriamente aperceptiva e real que nenhuma análise abstracta, generalizante, nominal, físico-fisiológica, está em condições de reconhecer. Para Biran é precisamente dessa ordem e da sua irredutibilidade que se trata de dar conta. Por essa razão, interrogará criticamente os sintomas de crise da nascente ciência do homem fascinada pelo método das ciências da natureza, pela análise das funções vitais e orgânicas, pelas traduções do humano em signos linguísticos e fisiológicos; e fá-lo-á com um escopo preciso: delimitar fronteiras e identificar linhas de demarcação para encontrar o lugar do propriamente humano do homem, ou seja, para finalmente poder elevar a problema filosófico a questão da existência pessoal consciente.

Contra todas as doutrinas que confundem pontos de vista ou tomam "o abstracto pelo simples e esse simples pelo primitivo, derivando o real do possível"16, há que começar a distinguir, "sempre na expressão como

${ }^{14}$ De l'aperception p. 83.

15 ID, o. c. p. 29, passim.

${ }^{16}$ ID, o. c. p. 63. A passagem merece ser registada: «Résumons ainsi en peu de mots les moyens appropriés à la recherche ou à la détermination des faits primitifs, et ceux aussi que nous croyons devoir employer dans la résolution des différentes parties du problème. Observer avant de classer, étudier chaque ordre de faits individuels dans sa source respective, chaque sensation spécifique dans le sens qui lui est propre, avant de généraliser le signe ou ériger en principe tel de ses caractère abstraits, attribuer chaque mode ou produit intellectuel, chaque état ou acte du sujet sentant et pensant, à la faculté ou au sens propre qui lui correspond, appliquer les sens externes et l'imagination aux choses senties ou 
na realidade", pontos de vista tão diferentes como aqueles que permitem considerar "um fenómeno tomado somente nos seus signos exteriores, ou na sua relação à consciência"17. Não que se devam negar as respectivas correlações empíricas entre - digamo-lo assim - o fisiológico e o psicológico; mas é forçoso compreender que os tipos de observação que respectivamente promovem e exigem não têm o mesmo fundamento, não falam de idênticos planos da realidade, não descrevem o mesmo tipo de encadeamento causal, não consideram o mesmo tipo de factos. Tese maior do biranismo - a sua "coluna vertebral", como lhe chamou F. Azouvi ${ }^{18}-$, a teoria dos pontos de vista sublinha a necessidade de ter em conta no estudo do homem, em razão da sua constituição mista e polémica, quer diferentes ordens de factos, quer diferentes tipos de conhecimento. Assumir tal premissa não significará, no entanto, concluir pela necessidade de escolher um dos pontos de vista ou tipos de conhecimento para nele se encerar; é precisamente o contrário que importa sustentar: a clarificação, na sua irredutibilidade, de cada um dos âmbitos e ordens de factos que, no homem, se oferecem apenas a cada um dos pontos de vista interior e exterior. Apenas deste modo se poderão obviar, segundo Biran, os perigos de todos os "sistemas mistos e propriamente contraditórios" 19 que, confundindo tipos de factos e métodos de conhecimento sob a pressão de uma equívoca uniformização epistemológica (acompanhada de anfibologias

représentées, l'aperception immédiate aux formes primitives du sens intime, une réflexion concentrée à la connaissance ou à la détermination des actes propres du vouloir et de l'intelligence, séparés ainsi des résultats sensibles avec lesquels ils se trouvent intimement combinés dans l'expérience, circonscrire enfin les limites de chaque sens ou faculté sans empiéter d'un domaine sur l'autre et en se gardant de confondre les bornes assignées par notre nature même à chaque ordre de faits extérieurs ou intérieurs, comme aux deux sortes d'observations qui s'y rapportent, telle est la méthode dont je voudrais pouvoir donner l'exemple en même temps que le précepte.»

${ }^{17}$ Décomposition, versão premiada, p. 37.

${ }^{18}$ Cf. AZOUVI, F., "La triplicité des points de vue sur le corps dans la philosophie de Biran", in Revue philosophique de Louvain, t. 103, n 1-2 (2005), p. 6.

${ }^{19}$ Décomposition, versão premiada, p. 49. «(...) En faisant ainsi concourir les deux méthodes, il serait extrêmement dangereux d'en confondre les limites et les résultas ou de renverser l'ordre de leur application et de leur emploi, de telle manière que l'on traitât par l'une les objets qui sont du ressort de l'autre; ce qui produirait des systèmes mixtes et souvent contradictoires, où l'on prétendrait d'un côté, par exemple, idéaliser et comme réfléchir la nature extérieur, de l'autre objectiver la pensée ou la mettre toute en représentation». Cf. Journal III, p. 244: «L'homme intérieur ne peut se manifester ainsi en dehors; tout ce qui est en images, discours ou raisonnement, le dénature ou altère ses formes propres loin de les reproduire. C'est là le plus grand obstacle que la philosophie puisse rencontrer, et cet obstacle est peut-être invincible par la nature même des choses». 
conceptuais), ora idealizam o mundo exterior, ora materializam o mundo interior $^{20}$ colocando-o todo em representações.

Uma verdadeira teoria dos limites deverá esclarecer que as fronteiras da ciência do homem não se podem traçar fora e independentemente do próprio sujeito consciente, do sujeito "actualmente constituído pessoa individual e inteligente, capaz de conhecer (...) e de se aperceber a sua própria [existência]"21. A física ou a físiologia não estão em condições de desenhar tais fronteiras. Desde o início da Décomposition, Biran afirma que no homem duplo "todos os modos que estão em dependência essencial e exclusiva das impressões dos órgãos externos ou internos, entram no domínio da fisiologia" e são passíveis de representação; mas todos os modos que "derivam da acção de um sujeito consciente da força que exerce ao produzi-los ou contribuindo para os produzir não podem ser caracterizados e reconhecidos senão dentro da reflexão." 22 Deste modo se assevera que no representável o eu não está presente, ao contrário do que sucede na reflexão, onde nos apercebemos imediatamente como causa das acções que podemos chamar nossas. Ora, tal diferença obriga a distinguir entre "saber fisiologicamente o que é uma impressão, um movimento, uma percepção [e] determinar como uma impressão é experimentada, como uma ideia é pensada, como um sujeito é possível"23. Apenas um saber que acompanhe a linha do esforço está em condições de compreender o que pertence ao sujeito ou é dele e o que não é, o que é confirmado pelo sentido íntimo e o que não é, o que é do estado de conscium ou compos sui e o que não é. Neste sentido, pois, Biran não recusará os resultados do saber objectivo, mas questionará os seus limites de aplicação; afirmará a dignidade epistemológica de um ponto de vista tomado no sentido íntimo, mas negará a pertinência de um qualquer enclausuramento egológico e transparente; traçará distinções e marcará fronteiras, mas não julgará separado o que se sabe unido, ou desconhecido o que se apercebe em exercício.

Explicitemos o aqui essencial. Destruir as falsas evidências construídas pelos dualismos mais variados, como pelos inatismos mais diversos, para recolocar a questão psico-física num ponto de acção dual em nós, conferirá, ao esforço biraniano um significado original: o de desvendar uma consciência

${ }^{20}$ Cf. De l'aperception, p. 62 n; num sentido análogo, Discours, p. 64. Cf. ainda Dernière philosophie: existence et anthropologie, p. 221.

${ }^{21}$ De l'aperception, p. 7.

22 Décomposition, versão premiada, p. 45. Nosso sublinhado.

${ }^{23}$ MONTEBELlO, P., La Décomposition de la pensée. Dualité et empirisme transcendental chez Maine de Biran, Millon, Grenoble, 1994, p. 76. 
que não é pura presença a si, mas actividade, que não é substância mas tensão, relação causal, acto que tem o corpo como elemento - um corpo que nasce nessa relação de esforço e a sustenta, corpo que sem deixar de ser muscularmente resistente, não reclama para ser conhecido qualquer representação das suas funções orgânicas ou traços anatómicos. Sustentar o carácter de facto primitivo nesse acto, equivale a afirmar que a presença do sujeito consciente é necessária ao conhecimento do que se passa no homem, que fora da relação entre vontade e corpo nada de "interior" se poderia conhecer, que nenhuma faculdade intelectual se poderia afirmar a existir, que nenhum dos sistemas sensitivo perceptivo ou mesmo aperceptivo se poderia dizer em exercício. E, de facto, em que outro lugar se poderá encontrar a origem do que pode significar "perceber", "recordar", "imaginar", "reflectir" senão do lado de um sujeito que se sabe no acto perseverante do seu próprio existir? Não podemos ignorar ou descartar a condição subjectiva do pensamento, a evidência da existência pessoal consciente, a certeza de si na variedade de uma existência psicológica complexa.

A génese plurívoca dos sistemas sensitivo, perceptivo e aperceptivo faz jogar a presença estruturante do esforço no centro de uma nova teoria das faculdades: estas têm a sua origem no próprio processo de diferenciação (no modo como se individualizam) a partir da variabilidade intensiva ${ }^{24}$ do esforço no encontro com a variação da matéria. Agir e pensar são, neste sentido, para Biran, idêntica operação activa de uma força que se desencadeia sobre um termo resistente. Começamos a pensar porque algo resiste ${ }^{25}$. Continuamos a pensar no exercício perseverante desse mesmo acto. A primeira das variações, o primeiro dos contrastes, a primeira das composições, é o próprio esforço. Todos os encontros e diferenciações ulteriores existem sempre para um $e u$ forjado como relação dual entre força e corpo resistente. Dito de outro modo, o primeiro

${ }^{24}$ Cf. Décomposition, versão premiada, p. 129: «D’un autre côté, nous trouvons par la réflexion que les modes de cet effort, qui persiste ou se reproduit incessamment de la même manière, ne diffèrent que par le degré d'intensité». Num mesmo sentido, ID, o. c., versão revista, p. 363, n. «Observez que l'effort considéré dans cette sorte de sensation musculaire que nous créons nous-même, ne peut varier qu'en intensité.»

25 O juízo de personalidade nasce de um primeiro contraste entre os dois termos da dualidade primitiva, e não entre duas sensações distintas, por exemplo, como defendeu ainda Destutt de Tracy. Cf. Correspondance 1766-1804, p. 310: «Mais le jugement selon vous ne naît que de deux sensations distinguées. Vous cherchiés (sic) donc un contraste, et vous ne le trouvés que dans la sensation d'un mouvement libre et celle de mouvement contraint, mais la relation n'est pas d'abord dans le contraste de deux modes, s'il faut qu'elle soit inhérente à l'un d'eux.». 
pensamento (o começo do pensar) não pode deixar de acompanhar essa resistência constrangedora e dócil que me enraíza na relação primitiva e me oferece a ocasião de me pensar, de me aperceber imediatamente o mesmo na diferença. Se o modelo dessas ideias tem a sua fonte no esforço, é porque aplicar-se a si na diferença não separada do esforço essencialmente relativo e reflectir não são actividades distintas. Eis a única base real do que se designa com os termos sentir, perceber, imaginar, recordar raciocinar, eis o fundo do critério de disjunção das faculdades, de diferenciação entre o que sinto enquanto localizo uma sensação no espaço interior do corpo, o que percebo enquanto reporto à extensão exterior uma resistência que não cede, o que apercebo num máximo de concentração Dos modos passivos produzidos na organização da simplicidade vital o eu é simples espectador e deles está sempre ausente; em contrapartida, no momento em que localiza e liga as impressões a uma causa, as afecções nascerão para ele como sensações, pelo que está nelas já presente; quando se une de maneira mais íntima aos modos dos quais participa ou para os quais concorre, é todo o sistema perceptivo que começa - o que quer dizer que na percepção se marca a acção do sujeito. Por fim, o eu do esforço é plenamente intensivo quando se encontra natural e indivisivelmente unido com os modos activos onde se reconhece como causa produtiva, distinguindo-se do efeito sensível determinado pela sua acção - nesses modos aperceptivos ou reflexivos não é senão ele na sua máxima definição e exercício.

$\mathrm{O}$ esforço, enquanto relação primitiva, entra em todas as relações e composições dos modos positivos do existir humano, fornecendo a base para a consideração real das distinções estabelecidas ou a estabelecer nos respectivos modos actuais; e, com ele, é o próprio corpo que se desvenda em inusitados modos de presença. Efectivamente, Biran não se limita a descobrir a presença do corpo na génese da consciência. A sua proposta de uma teoria ontogenética das faculdades, estabelecida a partir do esforço, leva-o igualmente a considerar o modo de presença do corpo em todas as faculdades intelectuais: em cada faculdade entra em jogo a própria dualidade primitiva e, por conseguinte, em cada uma desempenha o corpo um papel determinado. Num certo sentido, podemos mesmo afirmar que não pensamos senão o corpo: o corpo da relação de esforço presente quando todas as sensações localizadas se ligam a um centro orgânico, quando todas as intuições se reportam a um mesmo espaço, quando todos os modos que dependem essencialmente da vontade se ligam à mesma causa $e u$ ou força produtiva única.

Para o filósofo de Bergerac, nenhuma ideia, nenhum pensamento, nenhum acto consciente, nenhuma faculdade, nenhum investimento da sensibilidade, enfim, nenhum sentimento, nenhuma experiência da existência 
pessoal acontecem sem corpo - e sem que a "palavra" silenciosa do corpo tenha sobre isso algo para "dizer". Mas tal não significa, deve notar-se, defender que as faculdades derivam ou se desenrolam num corpo objectivo. É bem, precisamente, o contrário que Maine de Biran ensina: a experiência da vida de consciência apenas se compreende desvendando na sua raiz uma ligação una na dualidade, real e mental, entre pensamento e corpo próprio; o mesmo é dizer que o sujeito consciente não pode ser entendido como um agregado de alma e corpo, de mente e corpo, porquanto a mente e o corpo são dimensões de uma consciência que não está dada de uma vez por todas, mas se conquista em cada momento e variação do esforço.

\section{2.}

No modo como regulou o debate com os dualismos metafísicos e os seus absolutos, Maine de Biran pretendeu sempre salientar a desproporção entre a linha da consciência (aperceptiva) ou da experiência da individualidade pessoal e as suas pretensas traduções positivas redutoras. É sob esse ângulo, de uma necessária consideração real da relação irrepresentável entre pensamento e corpo, que identifica o momento genésico do pensar - da consciência de si - a uma dualidade primitiva que, no esforço, é modo completo sob o título de apercepção. Neste contexto, qualquer tentativa de traduzir o pensamento num corpo disponível, ou de dissolver o corpo em traduções espirituais será equívoca. Afirmar que o eu conciente é uma dualidade em acto, implica sustentar que o mais primitivo e real no homem escapa à representação, mas permanece evidente no exercício perseverante de si. Será sempre absurdo, portanto, generalizar o individual, exteriorizar o interior, simbolizar o que é sem figura, objectivar o irrepresentável - seja esse "individual", esse "interior", esse "sem figura", esse "irrepresentável" do pensamento ou do corpo. Este aspecto é decisivo para Biran, que questiona: "será que todos os modos, ideias ou actos que entram no entendimento, podem ser submetidos por igual a um ponto de vista exterior e apreendidos nos traços materiais de impressões recebidas? Não são essas impressões elas próprias em alguns casos produtos de actos apercebidos antes delas ou sem elas? Não haverá pensamentos, volições íntimas que de maneira alguma se possam ler no exterior, nem ser representadas por qualquer tipo de imagem? Para as conceber não será necessário estar identificado com a força activa e conscientemente produtora de tais actos: com o eu que não se vê como objecto nem se imagina como fenómeno?"26

${ }^{26}$ Décomposition, versão premiada, p. 326. 
A linha do esforço aperceptivo não pode ler-se no exterior ${ }^{27}$, nem "representar-se por qualquer tipo de imagem"28 ou "jogo especular" 29. O mesmo é dizer que tentar manifestar a consciência, traduzir exteriormente o pensamento, localizar as faculdades estará muito longe de poder representar a respectiva explicação verdadeira. Tal afirmação não é inocente; antes visa directamente toda uma história de pensamento que se prolonga nas promessas funestas de "um paradigma da manifestação" 30. Biran vê esse paradigma preparar-se "na escola de Descartes" e no animismo de Stahl, dar os primeiros passos, por exemplo, na neurobiologia em miniatura de Bonnet ou nas observações de Hartley, nas propostas de Cabanis, nas confusões de Pinel ou, paradigmaticamente, nas propostas frenológicas de Gall. A Biran repugnará este fascínio pelo representável que, procurando conhecer o que é do $e u$ fora e independentemente do $\mathrm{eu}$, deturpa os factos interiores, apaga as diferenças, ignora as bases reais do conhecimento, violenta e desfigura a actividade singular. Por essa razão, questionara a hipótese comum a todas as doutrinas e sistemas que se desenvolvem sobre "o princípio metafísico implícito de uma possível revelação espacial e material do espírito"31 num corpo reduzido ao seu "exterior", para denunciar um duplo erro: a ilusão de visibilidade do pensamento (das faculdades activas) e a redução do corpo à saturação do seu próprio exterior representável. Igualmente investigará, de modo crítico, as grandes justificações que vislumbra suportarem o pressuposto (arbitrário) de que o pensamento, as faculdades, o subjectivo, o pessoal, podem ser explicados representativamente num qualquer "relevo sensível": "relação causal", "ligação de identidade" e "ligação simbólica"32.

Biran sabe bem a que ponto podem ser fascinantes tais teorias e tais justificações. Não poderia, pois, ignorar, por exemplo, a influência exercida por Gall e pela sua promessa de ver o pensamento, tocar as faculdades mais interiores, ler em "signos puramente exteriores" o propriamente humano do homem, palpar o moral no físico.

Trata-se de um exemplo paradigmático. Exclusivamente preocupado com a observação exterior da ligação entre as faculdades mentais e o cérebro através das protuberâncias que as primeiras inscreveriam no

27 JD, o. c. versão premiada, p. 24.

${ }^{28}$ ID, o. c., versão revista, p. 326.

${ }^{29}$ ID, o.c., p. 305. Cf. MONTEBELLO, P, La décomposition de la pensée, o. c., p. 32.

${ }^{30}$ MONTEBELLO, P., Nature et subjectivité, o. c., p. 26.

${ }^{31}$ ID, «Maine de Biran. Les relations entre corps et esprit», in QUILLOT, R., (Dir.) Le corps et l'esprit, ellipses, Paris, 2003, p. 101.

32 Dernière philosophie: existence et anthropologie, p. 22. 
crânio, Gall não considera o sentimento interno de uma distinção reflexiva interna das faculdades intelectuais, antes julgando possível esclarecer o que significa pensar através de uma proposta de disseminação de elementos materiais. Suspende, pois, implicitamente a base reflexiva sobre a qual, apenas, se funda a possibilidade primitiva de compreensão dos factos interiores e encerra-se no pressuposto epistemológico segundo qual só se pode conhecer o que a imaginação pode localizar ${ }^{33}$. Por essa razão proporá, contra tudo e contra todos (mesmo contra os resultados das suas primeiras investigações), que qualquer disposição do espírito deve traduzir não só uma determinada competência, mas uma intervenção sobre a superfície física do corpo. O "princípio metafísico implícito de uma manifestação física do moral", o primado de uma "representação simbólica" acessível a um novo protocolo de observação - a palpação das bossas do cérebro -, enfim, o pressuposto de que as faculdades "mais íntimas" são visíveis num relevo sensível orientam a investigação frenológica ${ }^{34}$. E com esse motor, desenha-se o sonho - feito para durar de tornar visível o pensamento num corpo sobre-representado. Biran cedo o denunciará.

Atento aos limites e equívocos dos pressupostos que a teoria frenológica torna evidentes no seu exagero empírico, Maine de Biran não se coibirá de afirmar que neles encontra a prova de que na história da filosofia e das opiniões dos homens, alguns dos sistemas e ideias mais absurdos "devem a sua origem ao abuso de algumas observações incontestáveis", e que alguns dos erros mais grosseiros "são o resultado de certas verdades às quais se dá uma extensão forçada, ou das quais se faz uma má aplicação." ${ }^{35}$ Por isso se aplicará a desmontar tais propostas: pergunte-se, desde logo, à craniologia de Gall - e a todas as hipóteses do mesmo género - onde primeiro se observa separado aquilo que se localiza num determinado ponto do crânio. Pergunte-se, igualmente, o que, em

${ }^{33}$ Cf. Discours, p. 50: «L'imagination, qui, représentant ce qui est hors de nous, s'attache exclusivement, dans la formation de ses tableaux, à ce qui peut se voir, se toucher, se décrire» implica um tipo de análise que é representativa, ou seja, de descrição exterior - será este o modelo seguido pelo método das ciências anatómicas e fisiológicas; por outro lado, «la réflexion qui, se concentrant sur ce qui este $\mathrm{n}$ nous, s'attache tout entière à ces modes les plus intimes, qui n'ont point, hors de la conscience, de signe de manifestation, ni d'objet ou d'image qui les mette dans un relief sensible» será o tipo de análise que deverá ser aplicado exclusivamente ao âmbito de uma ciência das ideias e das faculdades do sujeito pensante, melhor, a uma ideologia subjectiva. Cf. AZOUVI, F., Maine de Biran La science de l'homme, Vrin, Paris, 1995, pp. 75-76; 154-155.

${ }^{34}$ Cf. Rapports, p. 60; Cf. Dernière philosophie. Existence et Anthropologie, p. 21.

35 Discours, p. 62. 
rigor, se entende por cada uma das faculdades que se nomeiam a partir da sua manifestação exterior. Investigue-se, ainda, a partir de que factos se estabeleceu esse saber. As dúvidas de Biran não são ingénuas. Visando inventariar as fragilidades da teoria frenológica ${ }^{36}$, confronta-a com um dilema: ou se parte da observação de um conjunto de crânios e se conclui que determinada protuberância corresponde a determinado fenómeno consciente e, deste modo, faz-se ciência sem se chegar a saber de que fenómeno consciente se trata; ou se parte da consideração do que o próprio observador entende por cada uma das faculdades que pretende localizar e se aprofunda reflexivamente o seu sentido, caso esse em que se conheceriam interiormente as faculdades intelectuais, mas se dispensaria o recurso à metodologia científica da observação exterior.

Que entre as condições vitais e as faculdades intelectuais existam determinadas correlações, não pode certamente ser negado; que os factos do sentido íntimo e as faculdades activas estejam ligados a determinadas condições materiais, sem as quais não existiriam, é também indiscutível. Mas será um erro supor que destas constatações seja possível retirar, como sua equivalente, a de que os fenómenos reflexivos e aperceptivos possam ser reduzidos às suas condições materiais e oferecidos ao olhar e ao tocar exteriores num qualquer relevo sensível. A relação de coexistência entre factos de natureza tão distinta (como o são funções orgânicas e actos da consciência ${ }^{37}$ ) "exclui toda a paridade, toda a analogia"38. Assim, que uma determinada zona da observação cerebral seja dita a causa, o símbolo, ou

${ }^{36}$ Cf. ID, o. c., pp. 65-66: «N'est-ce pas, par exemple, une disposition toute artificielle que cette coquetterie qui ne naît dans la femme qu'au moment où elle tend à échapper à sa destination naturelle, à changer l'ordre de l'attaque et de la défense, à feindre la résistance quand elle aspire à la défaite, et l'intention de se rendre quand elle en est le plus éloignée? Pourquoi donc accuserait-on la nature d'avoir fait à certaines femmes une nécessité de cet artifice, en leur donnant l'organe de la coquetterie? Et comment ce prétendue organe se trouverait-il distinct de celui de la ruse, de celui de la vanité, de celui de l'orgueil, car il y a aussi des organes pour toutes les dispositions, qui ont cependant tant de rapports entre elles, qui ne sont guère que des nuances ou des empreintes d'une même type fondamental? L'organe de la coquetterie se trouve-t-il donc aussi chez les femmes des Hurons, des Iroquois et des Hotentots? L'organe vol existait-il chez les Spartiates qui ne connaissaient point la propriété, ni la différance du tient et du mien? Est-ce donc enfin que la nature a dû varier les formes du cerveau et les protubérances du crâne, suivant les moeurs et les usages des différents peuples, suivant les degrés de civilisation, suivant les conventions et les lois de la société?»

${ }^{37}$ Cf. Décomposition, versão premiada, p. 33 ; Cf. ID, o. c., versão revista, p. 322. Cf. Discours, p. 57.

${ }^{38}$ ID, o. c., p. 39. 
o $\operatorname{lugar}^{39}$ das faculdades é uma afirmação que, para Maine de Biran, carece de fundamento.

A frenologia representa bem uma primeira tentativa sistemática de ligar, para lá de qualquer dúvida, o pensamento, o espírito, as faculdades intelectuais e a estrutura orgânica. Em cada bossa palpável sobre a superfície exterior do crânio são essas faculdades que se julga poder transpor para o exterior, ignorando a sua imaterialidade e irrepresentabilidade para as tornar imagem disponível ao observador exterior. Para Biran, a violência assim feita aos factos do sentido íntimo é clara, a deturpação da realidade das faculdades evidente. O mesmo é dizer que se a ciência do homem seguir esse caminho tombará num impasse: a homogeneização de factos distintos apenas poderia ser feita em função de fenómenos definíveis operatoriamente e susceptíveis de manipulação metodológica; mas se se assumisse que todos os fenómenos são redutíveis a causas ponderáveis metodologicamente e determináveis experimentalmente, optar-se-ia por considerar esses fenómenos renunciando a definilos na ordem da experiência ou, o que é o mesmo, a negá-los como Erlebnisse. Ora, precisamente, procurar a essência do pensamento no seu suporte material, silenciando a necessidade reconduzir a investigação das faculdades à respectiva base real (o sujeito aperceptivo), equivale a perder a individualidade pessoal, o movimento próprio da consciência, o processo de diferenciação das faculdades estabelecido no esforço: ou seja, o que é o mesmo para Biran, equivale a perder a própria possibilidade de um conhecimento não deturpado dos factos propriamente humanos. Porque, efectivamente, os factos "interiores", ou sem figura não são susceptíveis de receber um grau de esclarecimento superior àquele de que gozam na fonte, onde é preciso necessariamente estudá-los para deles se formar ideias propriamente reflexivas" 40 : o " $\mathrm{eu}$, como sujeito pensante primitivo de consciência" 41 .

Será com estas considerações, que balizam o diálogo com Gall, que o debate biraniano em torno do diagnóstico ou antevisão da "crise," da ciência do homem se aprofunda: tal crise radica numa avassaladora uniformização epistemológica (empobrecedora da noção de experiência), ou tentativa de transpor para o estudo do homem os mesmos princípios metodológicos das ciências da natureza, os mesmos processos de generalização, o mesmo primado da representação exteriorizante. Ora, comprometer-se com a crença, ilusória, de que é possível objectivar, de

\footnotetext{
${ }^{39}$ Dernière philosophie: existence et anthropologie, p. 22.

40 Rapports, p. 47.

${ }^{41}$ ID, o. c., p. 53.
} 
que é possível ler mesmo a dimensão pessoal do existir, de que é plausível compreender um pensamento numa imagem ou "relevo sensível" - ou seja, um pensamento sem pensamento -, equivale a supor que numa qualquer tradução material se pode descobrir o eu consciente, a experiência corporalizada de si, a individualidade pessoal.

Tal sonho permanece vivo hoje em muitas das promessas das modernas neurociências, apoiadas em todo um poderoso conjunto de novas técnicas de observação do cérebro. E, como ontem, poderíamos dizer que continuam sem interrogar o próprio projecto de que se nutrem: o projecto de localização do pensamento, de manifestação integral do humano. O sonho de cartografar o pensamento, de vislumbrar "uma ligação muito directa entre o psíquico vivido e o fisiológico registado" mantém-se vivo, por exemplo, no discurso do neurocientista J.-P. Changeaux. Na década de noventa do século passado, em inolvidável diálogo ${ }^{42}$, afirmou-o ao filósofo P. Ricoeur que, crítico, como Biran havia sido frente a Gall e quase com as mesmas palavras, observará: é na passagem, na "relação entre o vivido e o registado, que reside um problema e não uma solução" ${ }^{43}$. O discurso da capacidade na área neuronal e na perspectiva do "homem capaz", não sendo idênticos, impedem uma identificação pura entre "o psíquico vivido e o neuronal observado." Neste sentido, defenderá Ricoeur, há que investigar a que ponto as neurociências medem realmente o desafio que se colocam a si próprias, com o projecto de cartografar integralmente a realidade do homem num "livro de imagens" 44 físicas ${ }^{45}$; mais, urge questionar se a experiência hermenêutica de si pode ser relamente modelizada experimentalmente sem prejuízo epistemológico, sem perda de sentido ${ }^{46}$.

Biran não se cansou de colocar as mesmas questões e de expressar as mesmas dúvidas. Para o filósofo, quaisquer análises físico-fisiológicas "por mais bem verificadas ou constatadas que sejam, mais não podem provar

42 CHANGEUX, J.P. e RICEEUR, P., Ce qui nous fait penser. La nature et la règle, Éditions Odile Jacob, Paris, 1998.

${ }^{43}$ ID, o. c., p. 75.

${ }^{44}$ ID, o. c., p. 68: «J.-P. Changeux - Les mots 'imagerie médicale', je vous l'accorde, font intervenir le mot 'image' dans le sens de 'livre d'images' ou de 'graphique'.»

45 ID, o. c., l. c. P. Ricœur - Vous partez d'une notion physique de l'image, par exemple comme projection optique d'un objet sur un autre.»

${ }^{46}$ Cf. ID, o. c., p. 90: «Paul Ricœur - Ma question est en fait de savoir si l'on peut modéliser l'expérience vécue de la même façon que l'on peut modéliser l'expérience au sens expérimental du mot. La compréhension que j'ai de ma place dans le monde, de moi-même, de mon corps et d'autres corps, se laisse-t-elle modéliser sans dommage? C'est-à-dire, sans dommage épistémologique, sans perte de sens.» 
que uma divisão ou separação real de funções fisiológicas"47; e destas divisões nenhuma "indução legítima" nos permite passar para a análise de uma divisão das faculdades ou operações da consciência. Nem tal, acrescente-se, é necessário: o que se passa em nós e depende da linha do esforço aperceptivo não é susceptível de receber um qualquer grau de esclarecimento superior àquele de que já gozam na sua fonte real: o eu como sujeito aperceptivo e reflexivo. Nenhuma análise representativa exteriorizante tem algo a ensinar-nos sobre a distinção das faculdades, ou sobre o sentido que se deve atribuir a cada uma. Ignorá-lo equivale a supor que o sujeito humano nada é para lá da representação espacial, da disseminação de funções, ou da uniformização localizada.

O paradigma de determinação integral do homem, que Biran vê concretizar-se em Gall, funda-se, no inquietante "princípio metafísico implícito de uma possível revelação espacial e material do espírito"48 e depende do pressuposto segundo o qual as faculdades se podem analisar "fora" do eu, no seu suporte orgânico. A violência extrema deste modo feita aos factos do sentido íntimo, forçados a aparecer e a coincidir com um exterior localizável para o filósofo de Bergerac, evidente: o reflexivamente apreendido na esfera da individualidade pessoal é como que retirado àquele que se sabe ser, ficando acessível, numa generalização necessariamente abstracta, ao perito que, do lado de fora, procede a uma decomposição objectiva das faculdades a partir da sua localização visível. Num certo sentido, o "sujeito é expulso da sua própria existência"49 e a sua verdade, a verdade da sua dimensão de ser, passará doravante pela inspecção anatómica anónima. Reduzir o pensamento ao visível, julgá-lo lizível numa imagem disponível, equivale, de facto, a supor que o condicional orgânico permite passar, por relação causal, tradução simbólica ou identificação completa, ao apercebido - o que configura um insustentável processo de biologização do pensamento, de fisiologização do psicológico.

Não estará em causa aqui uma crítica de cabeça baixa aos procedimentos científicos. Biran não ignora, já o anotámos, a necessidade de considerar as devidas ligações entre o físico e o moral. O problema começa no momento em que, obliterando-se as diferenças e julgando-se possíveis todas as analogias indevidas, se pretender reduzir o aperceptivo às suas condições orgânicas: estas últimas serão certamente condições

${ }^{47}$ Discours, p. 63.

${ }^{48}$ MONTEBELlO, P., «Maine de Biran. Corps et esprit», in QUILLIOT, Roland, (Dir.) Le corps et l'esprit, ellipses, Paris, 2003, o. c., p. 101.

${ }^{49}$ ID, Nature et subjectivité, o. c., p. 28. 
necessárias daquelas, mas não as condições suficientes. Neste sentido, o rigor da explicação fisiologia deve medir-se pela respectiva capacidade em deter-se nos seus próprios limites e, a partir deles, indicar uma ordem de factos que não tem competência para estudar. Todos os sistemas de explicação, sejam ideológicos, frenológicos, craniológicos, trilham, na perspectiva do filósofo de Bergerac, a "assimilação ilusória, perpetuamente estabelecida entre os fenómenos do $\mathrm{eu}$ individual" e uma "ordem de factos absolutamente estranhos ao eu" 50 e passíveis de localização ou representação; ou seja, todos, de um modo ou de outro, acreditam que a condição orgânica pode "produzir" um suposto condicionado psicológico. Uma ligação existe (veja-se, por exemplo, os casos observados de lesões cerebrais); mas há que questionar outrossim a possibilidade de encontrar no orgânico o significado propriamente humano do pensamento, das faculdades.

É contra a tendencial hegemonia do primado representativo que Biran proporá o aprofundamento de uma investigação da dimensão originária e irrepresentável do propriamente humano numa ciência do homem. Esse propriamente humano constitui-se - interessa-nos voltar a sublinhá-lo seguramente, numa relação ao corpo, mas a um corpo apropriado, interiormente percorrido, sem figura, ressoante. O esforço biraniano consubstancia, então, a certeza de que "o homem interior não se pode manifestar assim no exterior, (...) de que tudo o que está em imagem (...) o desvirtua ou altera as suas formas longe de as reproduzir" ${ }^{51}$; o esforço confirma, pois, a possibilidade de redescobrir corporalizadamente a certeza não representativa de si.

3.

O esforço, enquanto estrutura dual primitiva da atestação, garantida por um mínimo de alteridade em acto, significa em Maine de Biran a indissociabilidade entre vontade e corpo, ao mesmo tempo que a certeza da condição corporal do pensamento. Não há pensamento, consciência, faculdades sem corpo. Desde logo, sem o corpo do esforço, resistente e consistente, corpo real enquanto próprio, concreto enquanto subjectivo corpo sem figura, uma vez que, enquanto elemento constitutivo da rela-

50 Rapports, p. 86.

51 Journal, II, p. 244. Cf. Essai, II, p. 276: «C'est en ramenant au sens de la vue les principes et la langage de la psychologie, qu'on a pu conduire à en exclure les faits de réflexion ou d'aperception interne, et à mettre ainsi tout le système intellectuel en représentations, toute la pensée en images». 
ção primitiva, não pode "em absoluto conceber-se como objecto, como coisa (...)"52.

Ora, assim ciente da condição corporal do pensamento, Maine de Biran não poderia ter deixado de reconhecer uma inusitada evidência: o pensamento, as faculdades activas, não vigoram ininterruptamente e sem falhas, antes sendo constantemente atravessados por algo que não constituem mas se lhe impõe, algo de um "outro" corpo que, recorrentemente, impõe as suas leis perturbadoras dos encadeamentos da consciência.

No seu Journal o filósofo de Bergerac dá testemunho das dificuldades diárias em manter o equilíbrio, a estabilidade propícios ao pensamento. Constantemente sofrendo a "falta de firmeza", o afastamento por relação ao "centro de gravidade" 53 , Biran confronta-se com a estranha fragilidade da vigência da posse de si. Em cada página desse texto magnífico, uma mesma ideia se regista: é difícil pensar, é difícil perseverar no exercício consciente de si. Como explicá-lo senão no limite da disjunção das faculdades, quando se encontra, para lá do regime do esforço, a sombra de uma vida impessoal em nós, os desígnios do "fluxo perpétuo" ${ }^{4}$, desmesurado e selvagem das afecções que ameaçam constantemente a consciência de desequilíbrio?

Caracteriza as afecções serem rebeldes à vontade e vazias de $\mathrm{eu}$ (e como foi criticada pelos contemporâneos de Biran esta tese de uma sensação sem $e u$ ), serem totalmente interiores ("esquivam-se à reflexão pela sua própria intimidade", dirá Biran ${ }^{55}$ ), sucederem-se, combinarem-se e misturarem-se incessantemente, formarem o fluxo de uma matéria sensitiva sem as "formas" de espaço, tempo ou causalidade subjectiva e radicarem-se nas "leis constantes e necessárias" que - enquanto "seres organizados vivos e sentientes" - nos "determinam sem se saberem" 56 . Num certo sentido, o fluxo das afecções parece vir de "parte alguma". Biran considerará que se trata do fatum $^{57}$ do corpo (do corpo vivo ${ }^{58}$ da organização ${ }^{59}$ ) operando em nós sem nós ${ }^{60}$, ou seja, furtando-se ao exercício da vontade.

52 Décomposition, versão premiada, p. 153, n.

${ }^{53}$ Note-se a repetição, no Journal, das expressões: «aplomb», «assiette», «être dans son centre», «centre de gravité».

${ }^{54}$ De l'aperception, p. 137.

${ }^{55}$ Discours, p. 29.

${ }^{56}$ Rapports, p. 24.

${ }^{57}$ Cf. Rapports, p. 3. «In mente est providencia, in corpore est fatum». A frase é de Leibniz.

58 Discours, p. 13.

${ }^{59}$ Cf. De l'aperception, IV, p. 68. Cf. AZOUVI, F., «L'affection et l'intuition chez Maine de Biran», in Les études philosophiques, janvier, mars, 1982, p. 80.

${ }^{60}$ Cf. Essai, II p. 214: «N'est-il pas en effet comme le destin, cet agent invisible de la vie qui opère en nous sans nous et dont nous subirions toujours les lois, alors même que ce qui est le fatum dans le physique deviendrait prévoyance dans le moral?.» 
A raiz das "lutas intestinas" 61 e "forças conspiradoras" 62 que operam em nós sem que as saibamos, permanece imemorial e irredutível a qualquer temporalização no presente. Se as sabemos presentes não é senão como o filtro ou o tom que "nos mostra a natureza exterior ora sob um aspecto risonho e gracioso, ora coberto de um véu fúnebre, que nos faz ver nas mesmas coisas, nos mesmos seres, ora objectos de esperança e de amor, ora motivos de desconfiança e de medo"63, que nos faz sentir, num mesmo momento, "alternadamente tristes ou divertidos, agitados ou calmos, frios ou ardentes, tímidos ou corajosos, desesperados ou plenos de esperança" 64 . Para dizer tal filtro como não consciente e infigurável, Biran serve-se da ideia de "refracção" (falando, então, de refrecção orgânica ${ }^{65}$, sensitiva ${ }^{66}$, animal $^{67}$, moral $^{68}$ ). Com esse conceito qual pretende esclarecer que o fluxo da vida impessoal não promove qualquer forma de temporalização ou causalidade consciente, mas apenas inversões inesperadas da consciência sobre um inexplicável que a assola recorrentemente. O exemplo das "variações do humor" é, neste contexto, exemplo significativo. Efectivamente, é ao jogo das simpatias afectivas que, desde logo, se deve a variedade dispersa, confusa e disseminada do sentimento geral de existência ${ }^{69}$, como o nosso modo particular de ser - ou seja, o nosso carácter, que não é mais do que a fisionomia ${ }^{70}$ do nosso temperamento e a marca distintiva da nossa singularidade ${ }^{71}$. Essa fisionomia permanece, no seu fundo, desconhecida, e sem qualquer "espelho que a reflicta aos seus próprios olhos, ou que a coloque em relevo fora dela própria"72. Não se negará a "expressividade"

\footnotetext{
61 Rapports, p. 133.

62 Discours, p. 25.

${ }^{63}$ ID, o. c., p. 29.

${ }^{64}$ Nouvelles considérations, p. 62.

${ }^{65}$ De l'aperception, p. 74.

${ }^{66}$ Discours, p. 29.

${ }^{67}$ Rapports, p. 98.

68 Décomposition, versão revista, p. 384.

${ }^{69} I D$, versão premiada, p. 91 .
}

${ }^{70}$ Cf., Nouvelles considérations, p. 62: «Aussi la partie de nous-mêmes sur laquelle nous sommes le plus aveugles est-elle l'ensemble de ces impressions immédiates de tempérament, dont ce que nous nommons caractère n'est que la physionomie.»

${ }^{71}$ Cf. Discours, p. 29, passim.

72 ID, o. c., 1. c.; Décomposition (versão premiada), III, p. 92. O temperamento ("modos variáveis do sentimento orgânico, fundamental, imediato da existência orgânica também chamada vida interior") escapa a explicações "espiritualistas", mecanicistas, animistas ou estritamente físicas. Cf. LE ROY, G., L'expérience de l'effort et de la grâce, Boivin \& Ca ., Paris, 1937, p. 225. O desenvolvimento do que Biran nomeia de "tacto interior", "afectivo"(Décomposition (versão revista), III, p. 294) ou "tacto imediato" (Rapports, VI, p. 110; Cf. Discours, V, p. 29) liga-se a este ponto. 
das afecções em todo um conjunto de comportamentos eruptivos que uma teoria dos signos simpáticos ${ }^{73}$ consegue identificar; mas permanece evidente a impossibilidade em que nos encontramos não apenas de conhecer a fundo os nossos semelhantes, como de manifestar o que somos em nós próprios ${ }^{74}$, ou justificar porque vemos o mundo e a vida de determinado modo. De facto, quando a vida afectiva se aviva é o nosso temperamento que mais frequentemente fornece às impressões acidentais exteriores "o tom em lugar de o receber". ${ }^{75}$ Tal deve-se ao facto da vida afectiva, que banha o nosso acesso ao mundo na sua mundaneidade, permanecer irredutível a toda e qualquer instituição simbólica e "indiferente" a todas as "coisas". Quando o tom da sensibilidade afectiva dita as suas leis cegas tudo se passa, de facto, como se irreflectidas "disposições, variáveis ou fixas" impregnassem os objectos ou as imagens de "certas modificações afectivas que lhes parecem próprias" com os seus "produtos", que são sempre "produtos não percebidos".

Embora $m u d a$, a presença da vida afectiva não deixa, pois, de fazer ouvir as "vozes do silêncio" de uma interioridade dissidente, perturbadora. Em rigor, as "causas" arcaicas das afecções e seu modo de formar o temperamento, colorir o modo como o mundo nos aparece, contagiar a "sensibilidade do coração"76, permanecem fora de qualquer movimento da consciência. Mas tal não significa afirmar qualquer "nada prévio" ao $\mathrm{eu}^{77}$; invoca-se, outrossim, um ponto cego da experiência consciente, formado pela comunicação e conjugação da multiplicidade de afectos entrecruzados, que se sucedem e substituem no corpo afectivo, influenciando de modo constante 78 e contínuo 79 "a direcção das nossas ideias e dos

${ }^{73}$ Décomposition, versão revista, p. 92. Para uma contextualização do importante tema da "simpatia", Cf. BOUCKART, B., «L'itinéraire de la sympathie», in Revue philosophique de Louvain, T. 103, 1-2 (2005), pp. 105-119. "[Maine de Biran] a tout d'abord utilisé ce mot dans le sens 'médicale' de l'époque, c'est-à-dire, comme fossile de la conception renaissante (...). Il évoluera ensuite vers une conception mixte dans laquelle la sympathie será une communication interpersonnelle fondée sur des 'signes sympathiques' avant d'opter, à la fin de sa vie, pour une conception nettement plus 'magique'.» A importância do tema não pode ser ignorada, tanto mais que é expressamente sublinhado no título da primeira conferência lida à Sociéte Médicale de Bergerac.

${ }^{74}$ Discours, p. 29.

75 Cf., por exemplo, Journal, II, p. 145.

${ }^{76}$ De l'aperception, p. 201, passim. Cf. Discours, pp. 42-43.

77 Bergson e, num outro sentido, Merleau-Ponty poderiam entrar neste debate. Cf. BARBARAS, R, Le désir et la distance Introduction à une phénoménologie de la perception, Vrin, Paris, 1999.

78 Nouvelles considérations, p. 132.

${ }^{79}$ Essai, II, p. 202. 
nossos pecados" - num ascendente tanto mais difícil de ultrapassar "quanto é desconhecida a sua fonte independente" 80 e tanto mais insólito quanto essa fonte está em nós mesmos.

Esse lugar de complicação ou invasão evidenciará ao mesmo tempo a refracção sensitiva e o seu poder de efracção que vem das profundezas do corpo afectivo, escondendo-se mas guardando de algum modo o seu poder de transpassibilidade (Maldiney) no campo da consciência. E não podemos ignorar este poder : reconhecemos, com efeito (Biran testemunhou-o em primeira mão), «as características e os signos dessas afecções próprias a cada parte da máquina animada" 11 ; ora, esse tipo de apetites e de excitações súbitas, "embora nasçam no coração ou no estômago", são capazes de se "estender por uma espécie de consenso, de se apoderar de toda a sensibilidade, subjugando a imaginação e acabando por absorver todo o sentimento do eu"82. Isto é, a persistência de certas disposições espontâneas da "máquina", movimentos automáticos do jogo orgânico - "que não está em nosso poder alterar"83 - podem "engolir" 84 , "absorver" 85 , desapossar ${ }^{86}$ o sujeito de si próprio, suspender progressivamente o exercício da vontade, obscurecer ou eclipsar totalmente o sentimento do $\mathrm{eu}^{87}$. Tombamos, então, em estados onde $o$ pensamento dorme, a vontade é nula, o eu está absorvido nas impressões sensíveis, a pessoa moral não existe ${ }^{88}$, as faculdades activas ficam prisioneiras de uma invasão total da sensibilidade interior ${ }^{89}$. Não é dizer pouco: a vida afectivo-intuitiva esboça uma ordem de desapossamento ou desapropriação capaz de substituir ao regime da "posse de si" um existir já dado (passivo) como um todo. Dos casos normais sono, sonho e sonambulismo aos casos derivados do magnetismo, dos estados de furor, delírio, alucinação ${ }^{90}$,

${ }^{80}$ Nouvelles considérations, p. 132.

${ }^{81}$ Rapports, p. 133.

82 ID, o. c., l. c.

83 Journal, III, p. 317-318.

${ }^{84}$ Discours, p. 28.

85 Nouvelles considérations, p. 81. Discours, V, p. 28. Tese cedo formulada em Décomposition, versão revista, p. 294: «Quand ces affections dominent, elles absorbent tout ce qui n'est pas elles.»

${ }^{86}$ Rapports, p. 140.

${ }^{87}$ Cf. ID, o. c., 1. c.

${ }^{88}$ Essai, II, p. 209; Cf. Décomposition (versão revista), III, p. 370.

${ }^{89}$ Essai, II, p. 253.

90 Que Biran divide em "externa ordinária" (implica a existência de um objecto exterior e pode ser compreendida) e "interior" (acontece na ausência de qualquer percepção real que possa contrariar a imaginação e leva a que a alucinado, preso a imagens que, distantes dos sentidos, impedem qualquer possibilidade de regulação, viva no eclipse do pensamento real). 
paixão ou devaneio ao sentimento confuso de "um modo anterior de existência", das perturbações que resultam das imagens fulgurantes da intuição aos casos radicais de mania e "alienação mental" ${ }^{91}$, uma mesma certeza se confirma, então: um poder orgânico carregado de ressonâncias, traços afectivos e imagens intuitivas selvagens desafia constantemente o poder da consciência, as orientações da vida afectiva podem chegar a perturbar as "determinações hiper-orgânicas (...), a direcção das nossas ideias, da nossa vontade mais reflexiva" 92 . O mesmo é dizer que o estado de conscium ou compos sui é constantemente minado do interior pelas forças do nescius ou alienus - tornando certa ao longo do nosso existir uma possibilidade que começou por ser verdade nos primeiros anos: homo vivit et est vitae nescius ipsae suae ${ }^{93}$.

Biran descobre, assim, um verdadeiro subterrâneo da consciência, um inconsciente, não psíquico mas somático ${ }^{94}$, que atravessa a consciência transtornando os seus encadeamentos próprios e obrigando a formular em termos novos a própria experiência da vida consciente: há modos do existir nos quais o $e u$ pode não estar presente. Não nos enganemos sobre o sentido destas observações: o inconsciente biraniano é radical e permanece o "espaço" onde coexistem as mais variadas orientações da vida, os mais bizarros ritmos de um corpo que permanece invulnerável ao tempo, à causalidade e ao próprio $e u$; em Biran não encontramos, pois, o paradoxo de um "consciente inconsciente", de um "inconsciente que pensa" com infindáveis estados de consciências desconhecidos entre si e para nós ${ }^{95}$, não encontramos um psiquismo "mais ou menos privado de consciência". As leis do inconsciente somático permanecem radicalmente estranhas e não coincidentes com a linha da consciência, formando o teatro (Deleuze) onde os investimentos do corpo afectivo agem como personagens de um drama - personagens sem sujeito ${ }^{96}$ capazes de se substituir totalmente ao próprio sujeito.

Contra a herança cartesiana e de todos os dualismos que fracturaram o cogito recorrendo à dialéctica do sujeito e do objecto, Biran conclui que a clareza do sujeito se pode obscurecer ou interromper no seu próprio centro, que a possibilidade de alienação se desenha pelo interior do próprio p. 236.

${ }^{91}$ Cf., por exemplo, Décomposition, versão revista, p. 388 ou Nouvelles considérations,

92 ID, idem, 1. c.; Cf. Nouvelles considérations, p. 132.

93 Dernière philosophie, p. 6.

${ }^{94}$ MONTEBELLO, P., «Maine de Biran: la relation entre esprit et corps», o. c., p. 106.

95 GIL, J., "Le problème de l'inconscient", in GIL, Fernando (coord.) Controvérsias científicas e filosóficas, editorial Fragmentos, Lisboa, 1990, p. 133-134.

96 ID, o. c., 1. c. 
cogito. Neste sentido, o princípio lógico cartesiano que separa o pensamento do eu aperceptivo, projectando-o numa entidade exterior, numa alma-substância que, enquanto se caracteriza por pensar, então, pensa sempre ${ }^{97}$, deve ser denunciado como ilusório. Para Biran, seria certamente mais verdadeira a variação sobre Descartes que P. Valéry proporá nos seus escritos: As vezes pensamos, logo, às vezes somos. Para o filósofo de Bergerac existir é, num certo sentido, não ser capaz de pensar sempre, não conseguir possuir-se sempre; numa palavra: é estar sempre exposto à possibilidade de alienaçã $o^{98}$ que a própria existência humana alberga como possibilidade. O cogito biraniano, sendo integral por força da descoberta da ligação entre pensamento e corpo, não poderá, então, deixar de se descobrir interiormente cindido, fissurado entre diferentes interioridades desenhadas por diferentes regimes de presença do corpo.

E é verdadeiramente surpreendente essa fissura, feita da bizarra alternância de uma corporeidade e corporalidade complexas. O corpo do esforço, disponível e disposto à relação de esforço, resistente e dócil, estrutura a interioridade aperceptiva propícia à posse de si; um corpo impessoal, furtivo à relação de esforço, qualitativo, variável, determina as paisagens insólitas de uma interioridade que não é de esforço e promove todas as formas de desapossamento. Deste modo, existir é bem acompanhar o ritmo interior de um drama (Ricoeur), testemunhado quotidianamente nas oscilações entre a harmonia e a desarmonia, o perseverar consciente, propiciado por um corpo interiormente resistente, e a presença em esgueire de um corpo subterrâneo capaz de embargar a linha do pensamento e orientar todo o conjunto de estados de falência da posse de si.

O melancólico ${ }^{99}$, segundo Biran, é quem "melhor sente a existência" nesses lugares de fronteira interior, onde se torna nítida a estranha cadência entre posse de si e desapossamento, consciência e inconsciência, certeza de si e investidas cegas de um vida afectivo-intuitiva exacerbada. Comprova esses limites na experiência da própria estranheza de não ser sempre e em todo o lado na sua própria existência, de ser depois de não

${ }^{97}$ Essai, I, p. 78.

98 Como ignorar um paralelo com L. Binswanger, E, Minkowski, von Weizsäcker, Szondi, E. Strauss, W. Blankenburg, M. Boss, H. Tellenbach, B. Kimura, entre outros. Cf. FÉDIDA, Pierre et SCHOTTE, Jacques, (dir.) Psychiatrie et existence (décade de Cerisy - septembre 1989), Millon, Grenoble, 1991. Cf. MALDINEY, Henry, Penser l'homme et la folie, Millon, Grenoble, 1997, nomeadamente, pp. 83-143; 251-295.

${ }^{99}$ Cf., por exemplo, Discours, p. 28; Nouvelles considérations, p. 67 ; 133; Rapports, p. 152 . 
ter sido, de não ser causa de todos os modos da sua existência, de não ser dono do seu tempo no fluxo qualitativo que passa sem duração, de não dominar o que a carne pode recordar, de pressentir a falência de si. Sob a forma de uma verdadeira infelicidade, o melancólico vive a constante expectativa de um eu que, nos limites do corpo pensável, assiste à possibilidade recorrente da sua própria dissolução, falta de apoio ou concentração, da sua submersão num corpo fluído e variável dos afectos - diante do que é um espectador placidamente conformado, já que sabe serem suas ${ }^{100}$ as possibilidades involuntárias do próprio existir. Ilustra, deste modo, a porosidade da linha de fronteira que se traça, em nós, entre a vigência da consciência num corpo apropriado e a presença dissoluta da vida num corpo que se esgueira, e se faz o esgueire por onde se perde a posse de si.

Mas como se reconhecem os limites do desapossamento? Ou o que é o mesmo: como pode chegar a fazer sentido o que permanece, no seu fundo, estranho à linha da consciência? No contexto da sua teoria dos "signos simpáticos"101 Biran considerou que um determinado conjunto de comportamentos "lacunares" se oferece, até certo ponto, ao observador atento como indicadores ou signos de estados dominados pela simplicidade vital; e acrescentou que para que tal aconteça, é necessário que aquilo que se observa ecoe simpaticamente no observador (por força de uma "comunidade de funções orgânicas, afecções imediatas e paixões simples"102) e suscite um qualquer significado de algo analogamente sentido. Como poderia ser isto possível senão sobre a capacidade de reconhecer, em nós próprios, como sintomas de ausência ou estranheza de si o mesmo esgueire perturbador do corpo afectivo?

Uma vez mais, o melancólico demonstra-o. "Perto dessas afecções imediatas", mas mantendo a necessária "força para se colocar de algum modo fora delas" 103 , sente a existência na fronteira porosa entre o que deriva do $e u$ e o que opera nele sem ele, entre a harmonia da posse de si

${ }^{100}$ Discours, p. 29.

${ }^{101}$ Décomposition (versão revista), p. 92. Para uma contextualização do importante tema da "simpatia", Cf. BOUCKART, B., «L'itinéraire de la sympathie», in Revue philosophique de Louvain, T. 103, 1-2 (2005), pp. 105-119. "[Maine de Biran] a tout d'abord utilisé ce mot dans le sens 'médicale' de l'époque, c'est-à-dire, comme fossile de la conception renaissante (...). Il évoluera ensuite vers une conception mixte dans laquelle la sympathie sera une communication interpersonnelle fondée sur des 'signes sympathiques' avant d'opter, à la fin de sa vie, pour une conception nettement plus 'magique'.»

102 Discours, p. 31.

${ }^{103}$ Décomposition, versão revista, p. 385, n. 
e a desarmonia do desapossamento; em cada momento de estranheza, no qual faz a experiência de algo que no seu próprio existir dispensa a sua vontade ou presença, reconhece, então, outros tantos sintomas de uma ausência de si. Em termos muito próximos daqueles que Ricoeur ${ }^{104}$ utilizará para analisar o sentido do inconsciente freudiano e o problema da prova em psicanálise, poderíamos afirmar que na experiência do melancólico se cumpre, então, a dupla condição requerida para que qualquer conteúdo inconsciente possa ter um efeito de sentido na interpretação de si: que na sua raiz permaneça o duplo radical e inconsciente do próprio suporte do sentido (o lugar de uma ausência do sujeito que permanece suporte do sentido a si próprio); que de origem de determinados comportamentos "lacunares", e por via de uma alteração de função, passe a motivo reconhecido de desapossamento, com incidência suficiente nos próprios sintomas de ausência para que o sujeito consciente neles se possa reconhecer como alienus - como um outro no lugar de si. Os "signos da afecções"105, como refere Biran nos Rapports, ao serem reconhecidos em cada oscilação da sensibilidade interior, transformam-se em outras tantas vias de uma hermenêutica de si, capaz de incorporar a lacuna ou ausência na mesma história de um existir polémico.

Tudo se passa como se, nas repercussões do corpo que somos e nos pode perder, um efeito de sentido promovesse sobre a consciência um efeito de sentido impossível de ignorar. O melancólico sabe-o bem; conhece o corpo furtivo das reacções espontâneas, das combinações bizarras e das imagens destemperadas, pressente-o no momento em que lança a sua sombra como um destino. Antes de todos os outros acompanha as suas variações, a sua fluidez; não certamente como conjunto de órgãos (que não deixa de ser), mas deixando-se apanhar pelos seus ritmos mais recônditos - que são os ritmos da vida, do mundo e dos outros em nós. O melancólico ouve "os gritos da actividade da máquina", sente-os aumentar ou parar enquanto "as ideias se sucedem, se detêm" e parecem mover-se ao mesmo ritmo. Poderíamos dizer, com um terminologia de $\mathrm{M}$. Richir, que reconhece esse corpo furtivo em phantasia ${ }^{106}$, como um todo indefinido, cinestésico, sem pontos de referência ou fronteiras definidas e constantemente escorregando para uma indefinição radical. A tristeza

104 Cf. GIL, J., "Le problème de l'inconscient", o. c., p. 137.

105 Rapports, p. 133.

${ }^{106}$ RICHIR, Marc, Phantasia, imagination et affectivité, Million, Grenoble, 2004. Cf. ainda RICHIR, "Stimmung, Verstimmung et Leiblichkeit dans la schizophrénie", in AAVV Conferências de Filosofia II da Faculdade de Letras da Universidade do Porto, Campo das Letras, Porto, 2000, p. 64. 
compadecida do melancólico é, num certo sentido, um mimar da influência perturbadora desse corpo numa captura sempre parcial do seu esgueire. Eis, a nosso ver, o significado de partilhar as penas desse corpo: com "um certo charme consolador" em estudá-lo, o melancólico segue "o seu percurso até às aflições e tristezas, ora para se colocar no lugar de um testemunho compassivo dos seus males, ora para encarar com sangue frio o inimigo interior" 107 no abismo de desapossamento que, em nós sem nós, constantemente repulsa e atrai.

Entre certeza de si e falência de si, razão e devaneio delirante, luz e sombra, a triste enfermidade do melancólico, a recorrente consciência da inconsciência de si, não poderão, pois, ser entendidas como figuras negativas de anormalidade ${ }^{108}$. Nessas oscilações sentidas, nessas repercussões imemoriais de uma vida fluida que nos atravessa em sucessivos assomos imprevisíveis, testemunha-se um existir polémico; e, de algum modo, encontra-se a fronteira de uma hermenêutica do sujeito corporalizado - de um sujeito que se testemunha e, até certo ponto, se "compreende" num devir como cadência, como ritmo histórico marcado pela alternância entre conscium e nescius, ipseidade e alienação ${ }^{109}$.

\section{4.}

Será, neste contexto verdade que, como afirma o filósofo de Bergerac, "nada há de mais instrutivo para o homem racional do que a história da loucura"110?

Ao estudar os casos patológicos de "alienação mental ${ }^{111}$, Biran defenderá que se devem compreender por uma "analogia perfeita" 112 com os fenómenos normais do sono, do sonho e do sonambulismo ${ }^{113}$ (que o levam a ponderar as análises fisiológicas do "imortal Buffon" 114 e do genial Bichat ${ }^{115}$, do "célebre Barthez"116 ou do "honorável amigo Cabanis"117), na exacta medida

${ }^{107}$ Discours, p. 28

108 MONTEBELLO, Nature et subjectivité, o. c, p. 37

${ }^{109}$ Cf. Rapports, p. 140.

${ }^{110}$ Recorde-se Discours, p. 105.

111 Cf. Essai, I, p. 225.

112 Discours, p. 84.

${ }^{113}$ Cf., por exemplo, Discours, p. 107: «Je pourrais montrer en second lieu comment les différents sortes de délire momentané ou de vésanies, d'aliénation mentale permanente, viendraient se ranger naturellement sous les mêmes titres de division que les songes (...).»

114 Cf. Discours, p. 83.

115 Cf. ID, o. c., 1. c.

116 Cf. ID, o. c., p. 85.

117 Cf. ID, o. c., l. c. 
em são também estados puramente afectivos ${ }^{118}$. A propósito da alienação mental se poderá falar, pois, de "sono do pensamento" 119 no sentido em que, sob o predomínio do inconsciente somático, a "condição primitiva e fundamental da inteligência" da "consciência ou da personalidade" está embutida, ausente ${ }^{120}$, "suspendida" 121 . Fazendo assentar a sua análise sobre a ideia de indivisibilidade entre consciência e vontade, Maine de Biran sustentará que se os poderes activos do espírito estiverem presentes, estão-no completamente e não se pode, em rigor, falar de alienação ${ }^{122}$; quando esses poderes activos são, por outro lado, perturbados no seu princípio sê-lo-ão também completamente ${ }^{123}$.

Tal tese é, no mínimo, polémica. O amigo Royer-Collard dirá que se trata de uma posição excessiva que nenhuma "observação" vem confirmar ${ }^{124}$. O desacordo com Pinel ${ }^{125}$, cuja concepção de alienação parcial será alicerce do "momento 1800"126, é também claro. Puro conservadorismo? Não o julgamos. Para Biran, as observações da nova psiquiatria não estão em causa; está sim em questão um problema filosófico de fundo: numa existência marcada pela possibilidade de uma alienação completa, onde e como se podem traçar as fronteiras da consciência? A resposta de Pinel, assente numa equívoca transferência para o estado de alienação de signos convencionais de certas faculdades nominais tomados do costume e entretanto ligados "a um centro particular, ou a uma divisão cerebral" 127 , que se passa a considerar fundar a divisão das faculdades, não é, para Biran, sustentável. Em tal proposta, estrutura-se a mesma história de pensamento que leva a Gall ${ }^{128}$.

118 Cf. Nouvelles considérations, p. 69: «(...) phénomènes dont les trois espèces pourraient être compris sous le titre général d'aliénation et se classer naturellement eu égard à l'analogie des circonstances ou des causes qui peuvent les amener, et eu égard aux sièges organiques qu'elles affectent et aux signes externes ou internes qui les manifestent.»

119 ID, o. c., l. c.

${ }^{120}$ Décomposition, versão premiada, p. 96.

${ }^{121}$ Nouvelles considérations, p. 69.

122 ID, o. c., p. 237.

123 ID, o. c., 1. c. Se o alienado aparenta faculdades activas, é como o sonâmbulo que parece realizar as tarefas do homem durante a vigília.

124 Cf. Nouvelles considérations, p. 268.

125 ID, o. c. p. 33.

${ }^{126}$ Cf. SWAIN, Gladys, Dialogue avec l'insensé, précédé de À la recherche d'une autre histoire de la folie par Marcel Gaucher, Gallimard, Paris, 1994, p. XXIX.

${ }^{127}$ Discours, pp. 62-63.

${ }^{128}$ Nouvelles considérations, p. 31. 
Pinel, de facto, não considera necessário aprofundar o sentido psicológico que é permitido atribuir aos termos com que trabalha para designar as faculdades da inteligência humana. Ignora também que por mais bem verificadas ou constatadas que sejam as análises fisiológicas "mais não podem provar que uma divisão (...) de funções fisiológicas"129; e lavra em múltiplas anfibologias terminológicas pois parece desconhecer que nenhuma indução pode ser feita legitimamente de uma análise fisiológica para outra "suposta paralela, das faculdades ou operações da consciência."130. Assume, deste modo, os equívocos de uma perspectiva puramente representativa sobre o homem. Ao não a interrogar, sustentará, então, acriticamente, que a distinção das faculdades se pode fazer derivar de uma divisão ou separação real de centros cerebrais; e, consequentemente, pressupõe que estando os centros cerebrais sempre em exercício e disponíveis à representação, assim também as várias faculdades que deles se fazem derivar o estarão. Para Biran, o erro é evidente: supõe-se que o suporte material orgânico é capaz de sustentar o exercício contínuo e sem quebras do pensamento, de que o físico é a chave para a compreensão do moral, de que a localização garante a permanência das faculdades ao mesmo tempo que traça os seus contornos. Eis uma perspectiva que acabará por conduzir a doença mental ao cérebro e alimentará o sonho de observação integral da loucura enquanto doença das faculdades humanas.

A separação biraniana entre ipseidade e alienação pretende obstar, defendemo-lo, a esta possibilidade, que só poderia ser sustentada por uma psicologia totalmente desvirtuada que julga poder identificar o seu objecto "com o de uma física ou uma fisiologia do cérebro"131. A questão é que a "passagem" da simplicidade vital à dualidade da humanidade, do ser vivo à pessoa existente não se traça de uma vez por todas sobre o orgânico, nem pode ser descoberta em qualquer tradução fisiológica. Sê-lo-ia se o eu derivasse da cinestesia, se a posse de si pudesse ser delimitada pelo desapossamento, se a ipseidade se encontrasse na alienação, ou o activo no passivo; uma investigação dos limites ${ }^{132}$ do físico e do moral revela, no entanto, segundo Biran, o contrário: é a posse de si que se pode reconhecer no limite do desapossamento, o $\mathrm{eu}$ espantando-se com as repercussões afectivas, a ipseidade na fronteira da alienação ${ }^{133}$, o activo resis-

${ }^{129}$ Discours, p. 63.

130 ID, o. c., l. c.

131 Rapports, p. 50.

132 ID, o. c., pp. 8; 269; Cf. Discours, p. 68 ; Cf. Rapports, p. 108.

133 Cf. Journal, II, p. 52: "Não tenho ideia de personalidade senão no ponto que separa o estado de idiotismo ou de alienação do de razão ou compos sui." 
tindo ao encadeamento do passivo. Porque é ainda nossa uma existência que se caracteriza pela possibilidade de um obscurecimento ou eclipse total do sentimento do eu - ainda nossa uma existência pessoal que se formula com o corpo no centro do pensamento, mas igualmente, com o corpo no seu limite. É bem verdade, enfim, que temos um corpo que permite pensar a existência e somos um corpo que obriga a sofrê-la e a experimentar a ausência de si.

\section{BIBLIOGRAFIA}

AZOUVI, F., "L'affection et l'intuition chez Maine de Biran", in Les études philosophiques, janvier/mars, 1982, pp. 79-90

AZOUVI, F., Maine de Biran La science de l'homme, Vrin, Paris, 1995

AZOUVI, F., "La triplicité des points de vue sur de corps dans la philosophie de Biran", in Revue philosophique de Louvain, t. 103, n. ${ }^{\circ}$ 1-2 (2005)

BOUCKART, B., "L'itinéraire de la sympathie", in Revue philosophique de Louvain, T. 103, 1-2 (2005),pp. 105-119.

CHANGEUX, J.P. e RICEUR, P., Ce qui nous fait penser. Lanature et la règle, Éditions Odile Jacob, Paris, 1998.

FÉDIDA, Pierre et SCHOTTE, Jacques, (dir.) Psychiatrie et existence (décade de Cerisy - septembre 1989), Millon, Grenoble, 1991. MALDINEY, Henry, Penser l'homme et la folie, Million, Grenoble, 1997.

GIL, J., "Le problème de l'inconscient", in GIL, Fernando, (coord.) Controvérsias científicas e filosóficas, editorial Fragmentos, Lisboa, 1990.

MAINE DE BIRAN, Mémoire sur la décomposition de la pensée, in Euvres de Maine de Biran, t. III, ed. Vrin, Paris.

MAINE DE BIRAN, De l'aperception immédiate. Mémoire de Berlin, in Euvres de Maine de Biran, t. IV, ed. Vrin, Paris.

MAINE DE BIRAN, Discours à la Société Médicale de Bergerac, in Euvres de Main de Biran, t. V. ed. Vrin, Paris.

MAINE DE BIRAN, Rapports du physique et du moral de l'homme, in Euvres de Maine de Biran, t. VI, ed. Vrin, Paris.

MAINE DE BIRAN, Essai sur les fondements de la psychologie (2 vol.), in Euvres de Maine de Biran, t. VII-1, VII-2, ed. Vrin, Paris.

MAINE DE BIRAN, Nouvelles considérations sur les rapports du physique et du moral de l'homme, in Euvres de Maine de Biran, t. IX, ed. Vrin, Paris.

MAINE DE BIRAN, Dernière philosophie. Existence et anthropologie, in Euvres de Maine de Biran, t. X-2, ed. Vrin, Paris. 
MAINE DE BIRAN, Commentaires et marginalia. Dix-neuvième siècle, in Euvres de Maine de Biran, t. XII-2, ed. Vrin, Paris.

MAINE DE BIRAN, Correspondance philosophique 1766-1804, in Euvres de Maine de Biran, t. XIII-2, ed. Vrin, Paris.

MAINE DE BIRAN, Journal (3 vol.), Édition de la Baconnière, Paris, 1954, 1955, 1957.

MALDINEY, Henry, Penser l'homme et la folie, Million, Grenoble, 1997.

MONTEBELLO, P., La décomposition de la pensée. Dualité et empirisme transcendantal chez Maine de Biran, Jérôme Million, Grenoble, 1994.

MONTEBELLO, "Maine de Biran. Corps et esprit", in QUILLIOT, Roland, (Dir.) Le corps et l'esprit, ellipses, Paris, 2003.

MONTEBELLO, P., Nature et subjectivité, Million, Grenoble, 2007, p. 23.

LE ROY, G., L'expérience de l'effort et de la grâce, Boivin \& Ca., Paris, 1937.

RICHIR, M., Phantasia, imagination et affectivité, Million, Grenoble, 2004.

RICHIR, M. "Stimmung, Verstimmung et Leiblichkeit dans la shizophrénie", in AAVV Conferências de Filosofia II da Faculdade de Letras da Universidade do Porto, Campo das Letras, Porto, 2000, p. 64.

SWAIN, Gladys, Dialogue avec l'insensé, précédé de À la recherche d'une autre histoire de la folie par Marcel Gaucher, Gallimard, Paris, 1994. 